\title{
Development of Macromedia Flash-Based Basketball Teaching Materials for Students' Physical Education, Sports and Health 10th Grade Senior High School Methodist 8 Medan
}

\author{
Firman Benhard Silaen ${ }^{1}$, Indra Kasih ${ }^{2}$, Novita Sari Harahap ${ }^{3}$ \\ ${ }^{1,2,3}$ Sports Education, Universitas Negeri Medan, Indonesia \\ firmansilaen7@gmail.com
}

\begin{abstract}
This study aims to produce learning media for basic basketball techniques based on Macromedia Flash for X grade high school students that can be used by students as a learning resource independently. The type of research used is research and development $(R \& D)$, namely the development of learning materials based on Macromedia Flash. This learning media development model was developed based on the ADDIE (Analysis, Design, Development, Implementation, Evaluation) development model. The subjects of the trial were students of class X SMA Methodist-8 Medan which consisted of small group trials of 15 students and large group trials of 30 students. The instrument used to collect data in this research and development is a questionnaire or questionnaire. The data analysis technique used descriptive statistical analysis. The results showed that the learning media for basic techniques of basketball based on Macromedia Flash for grade X SMA students were feasible to be used as a learning resource for students. This is indicated by several assessments that have been carried out by media experts, material experts and field trials. The final result of the assessment of the media expert shows that the basic basketball technique is declared "very good" with a percentage of $86 \%$ and the results of the assessment of the material expert show the category of "very good" with a percentage of $85 \%$. The results of the small group trial got the "Good" category with a percentage of $90.76 \%$ and the results of the large group trial got the good category with a percentage of $95.38 \%$.
\end{abstract}

Keywords

reflector learning style; learning media; basic basketball techniques, macromedia flash

\section{Introduction}

Education is a means of forming human personality in gaining knowledge and skills from teachers to students to achieve predetermined goals. The advancement of technology today can affect the field of education. Education in the current technology era requires teachers to be able to operate computers / laptops and make innovations in order to provide a new atmosphere in the learning environment. Education must really be used as a foundation so that the use of technology can be applied effectively by teachers as education providers, because education is a gateway for anyone to receive knowledge in order to improve human resources to be more qualified (Haryanto, 2015).

Education is key to the progress of a nation. As Iwantoro has put forward (2014:53) education is a very important issue in the development of this nation and the country. The purpose of Education is to direct the growing potential of learners to be a man of pious care to the One God Almighty, qualified, possessed of sublime pekerti ability and virtuousness. Education has a very strategic role in determining the direction of the forthcoming of the nation's quality of community knowledge. (Musdiani et al. 2019) 
The development of science and technology increasingly encourages renewal efforts in the use of technological results in the learning process. It can be said that the world of education today lives in the world of media, where learning activities have moved towards reducing the delivery of conventional learning materials that prioritize lecture methods, and replaced with modern learning materials delivery systems that emphasize the role of students and the use of multimedia.

Conventional teaching has a major drawback, namely teacher-centered teaching. Teachers have full control in the teaching process, while students are only learning objects. Students are only learning objects, so the learning process of students is not optimal. Students do not get wide opportunities in developing thinking skills so that cognitive competencies are weak. Students are less motivated and the learning response is weak because teaching is centered on the teacher and there is no direct learning process.

Such conditions require teachers to be more innovative in finding or making learning strategies and learning media that are attractive to be able to foster interest in learning so as to support the learning process. This is in accordance with Hernowo (2005: 19) if a person does not appear passionate about teaching or learning about the things he is teaching or learning, then in the teaching-learning environment it is rather difficult to say that there is joy. The second problem is more caused by the condition of the learning system prevailing in SMA, which is generally classical. In classical learning, of course, differences in individual competencies cannot be maximally appreciated. Each individual has different body shapes and mental characteristics such as intelligence, memory, motivation, appreciation, reasoning, and different wills.

Psychologically, high school students tend to like new things that are modern and sophisticated. This characteristic is what makes the teacher foothold in finding the right media. Media that suits the characteristics of high school students is Macromedia Flash. Macromedia Flash will be more attractive to students than the use of the lecture method in class. Macromedia Flash which contains a reading learning package that is packaged so that it attracts students to control the pace of each learning speed. Macromedia Flash learning is interactive in the sense that it has the ability to accommodate user responses.

Macromedia Flashis computer-based multimedia. Multimedia means the collaboration of various media which is realized through a computer system application program so as to produce media in the form of text, sound, and images. Facilitating various learning models desired by the teacher. The existence of a combination of many media allows students to be actively involved in developing their creativity and allows students to learn independently. This is in accordance with Koesnandar (2003: 8), that the purpose of multimedia assisted learning is to make students involved and more active in learning, make communication more effective, facilitate forums, and increase interest and motivation to learn.

The use of interactive media is very useful to help the communication process between teachers and students be more effective. Audio-visual media can be interpreted as a tool used in a study room or in other learning situations to facilitate understanding of written and spoken words. Several factors in the philosophy and history of education, what is known to humans (knowledge) is transmitted to the brain through one or more senses. Many experts argue that $75 \%$ of human knowledge reaches the brain through the eye and the rest through hearing and other senses.

Learning is essentially a cognitive process that has the support of psychomotor functions. The psychomotor function in the learning manifestations carried out by students, almost certainly always involves a function of the realm of reason whose intensity of use is certainly different from other learning events. (Arsani, et al. 2020) 
Learning media is a tool or media that functions to convey messages in a teaching. With the help of the application, it is hoped that it can improve the results of student knowledge, arouse desire and interest, generate stimulation motivation during practice in the training field, help the effectiveness of delivering messages, increase understanding, present data in an attractive and reliable manner, facilitate interpretation, and condense information. Learning models like this are expected to help in the process of delivering messages from educators or teachers to students with media that is fun for students.

Based on this background, the authors are interested in researching "The Development of Macromedia Flash-Based Basketball Teaching Materials on Sports and Health Physical Education Lessons in Class X Students at SMA Methodist-8 Medan."

\section{Research Methods}

The type of research carried out is ADDIE development research model developed by Dick and Carry to design a learning system (Endang, 2013: 200). The ADDIE model uses five stages of development, namely analysis, design, development, implementation, and evaluation. The subjects in this study were 15 students for the small group test and 30 students for the large group test. The data obtained during the study were analyzed based on instrument analysis, analysis of the validation results of media experts, basketball learning material experts, and analysis of student response questionnaires. The learning media design developed is as follows:

\subsection{Basketball Initial Display}

The initial appearance of the learning media displays the media title and the short profile of the researcher. In the initial display there is a maximize button to display the fullscreen screen, an "exit" button to exit the full screen screen and an "enter" button to enter the learning media. These three buttons will appear on each display of instructional media. The initial appearance of the developed learning media can be seen in Figure 1.

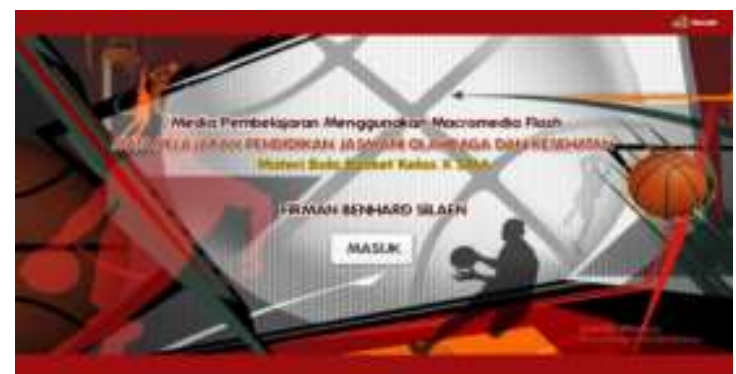

Figure 1. Initial display of Mediaflash Macro-based Learning Media

\subsection{Main course}

The main display of learning media. In the main menu there are menus: notification, introduction, introduction, material, evaluation, profile. As shown in Figure 2.

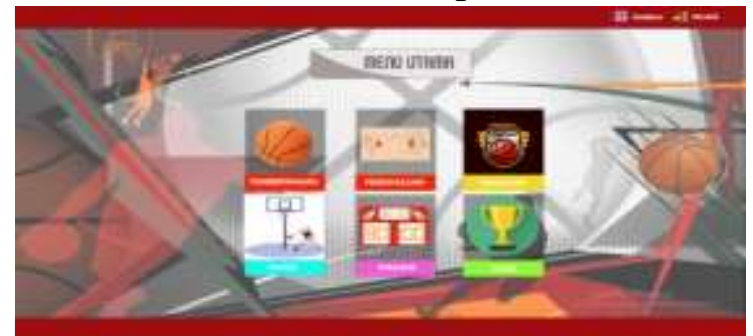

Figure 2. Main Menu Display Mediaflash Macro Based Learning Media 


\subsection{Notification menu}

On the notification menu that shows the function of each button on the learning media. As shown in Figure 3.

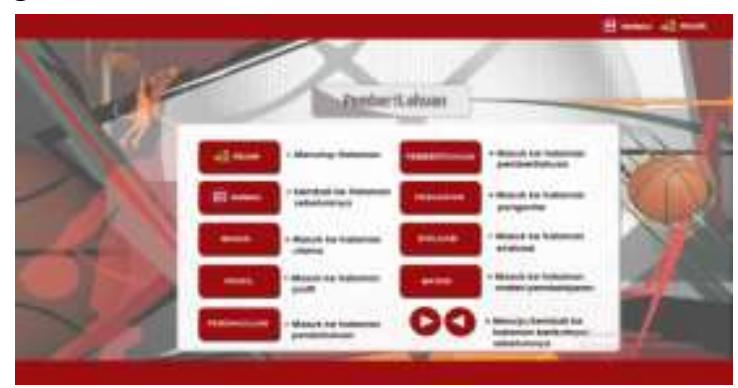

Figure 3. Display Mediaflash Macro Based Learning Media notification

\subsection{Menu Introduction}

The introductory menu contains basic competencies, learning indicators and learning objectives taken from the learning syllabus for class X SMA as shown in Figure 4.

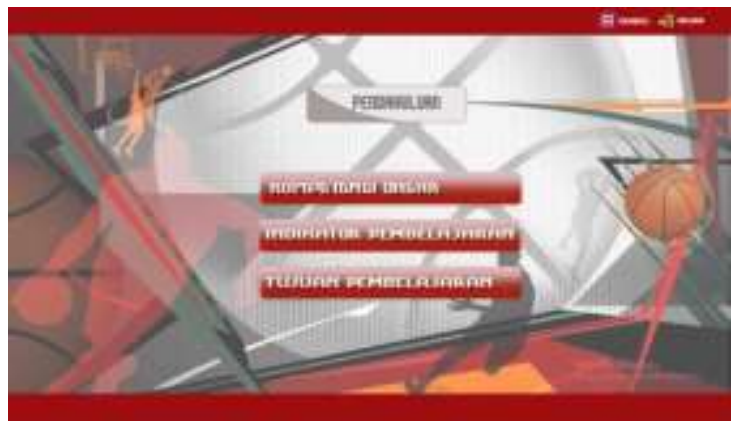

Figure 4. An introductory view of Mediaflash Macro-based Learning Media

\subsection{Introduction}

The introductory menu contains the history of basketball and basketball infrastructure as shown in Figure 5.

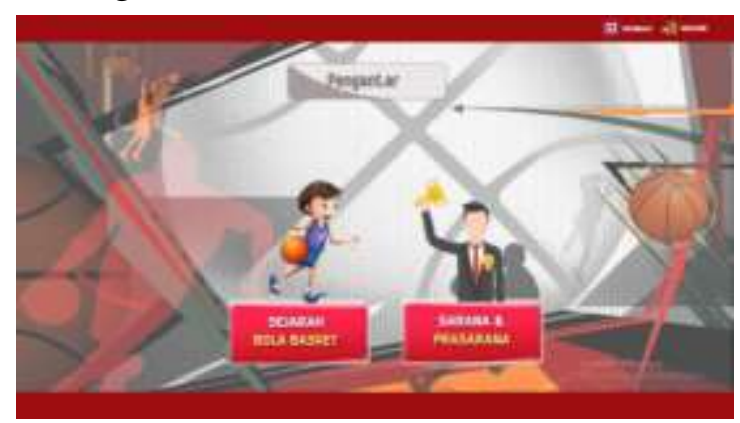

Figure 5. An introductory display of Mediaflash Macro-Based Learning Media

\subsection{Menu Material}

In the material menu presents a selection of materials on this media, the material displayed consists of learning material about passing, dribbling, shooting, and laying up. In each sub menu, the understanding of passing, dribbling, shooting and lay-up is packed, which is supported by doing the movements along with the video tutorial for doing these moves as shown in Figure 6. 


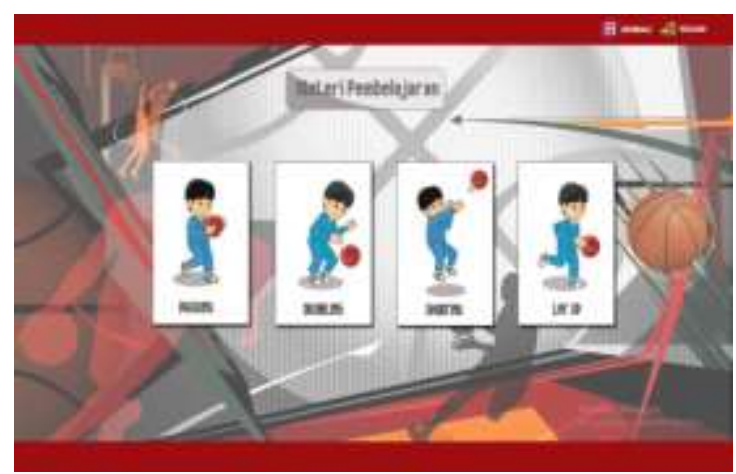

Figure 6. Display material menu on Mediaflash Macro-Based Learning Media

\subsection{Evaluation}

On the evaluation page, there are instructions for doing evaluation. After pressing the start button on the evaluation it will enter the question page. The time to do the questions is 10 minutes each about one minute. After finishing working on the question press the Finish button and the results of the work on the question will appear. If you haven't finished answering and the time has run out, it will automatically display the questions. To display the question page as shown in Figure 7.

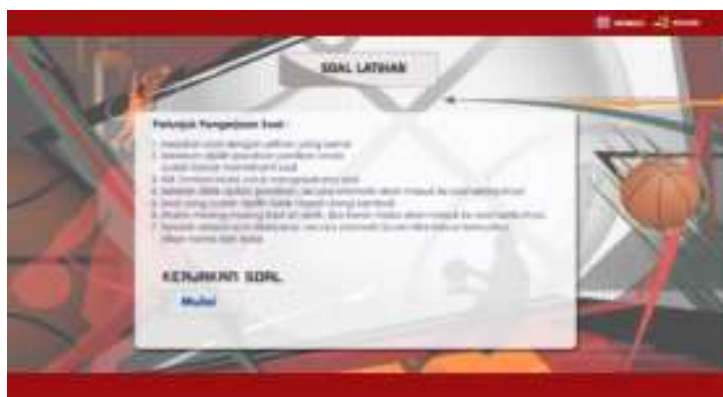

Figure 7. Display the Evaluation menu or practice questions Mediaflash Macro-Based Learning Media

Figure 8. Display sub menu evaluation or practice questions Media Flash Macro-Based Learning Media. 


\subsection{Profile}

On the profile page there is a profile of that developer. Profile page as can be seen in Figure 9.

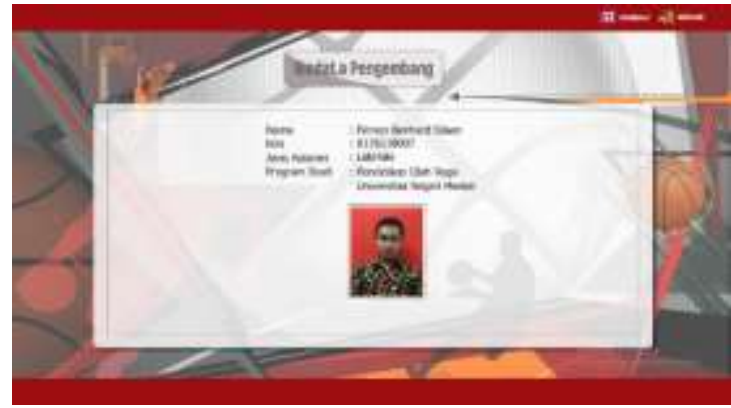

Figure 9. Display menu Profile or developer bio-based Learning Media Mediaflash Macro

\section{Results and Discussion}

Based on the explanation of the problem formulation, points have been obtained which are the objectives of the development of Macromedia flash-based materials, namely as follows: This development uses the Research \& Development (R\&D) method. Research \& Development (R\&D) or Research and Development. The model or approach to instructional media design is the ADDIE model which consists of several stages, namely: (1) Analysis; (2) Design; (3) Development; (4) Implementation; (5) Evaluation.

The first stage is the analysis stage. In the analysis, there are 2 stages. Needs Assessment (Needs Analysis) in the form of analysis of the situation in the field and participants as well as collection of reference material that will be the subject of discussion in media development. The results of information regarding the learning process, student characteristics and the development of learning media were obtained from observations carried out when carrying out learning in 2019 in the Basic basketball learning activities at SMA Methodist-8 Medan class X. Next activity Front-end Analysis by collecting references in the form of curriculum, syllabus for Basic Basketball subjects, as well as books related to material and others needed in developing multimedia-based interactive learning materials or interactive learning. The results of the analysis of the curriculum, then selected 1 Basic Competency (KD) which became the target of development. The main material of these basic competencies is about the basics of.

The second stage is Design. The design stage is the stage of designing interactive learning media which includes the formulation of objectives for making interactive learning media. Basic Graphic Design, making folwcharts, making storyboards, collecting design objects, and compiling feasibility test instruments. The third stage is Development. This development stage is the stage of creating and developing learning media from all the components that have been prepared into a complete unit according to the flowcharts and storyboards that have been designed using Macromedia Flash Professional. After the media has been made, validation is carried out by media expert lecturers and material expert lecturers, to obtain input on development accompanied by an interactive learning media feasibility assessment instrument.

The fourth stage is implementation. At this stage the interactive learning media that has been developed are then implemented to class X MIA SMA Methodist-8 Medan. This implementation aims to determine student responses to the developed learning media based on Macromedia flash. From this stage it will be known the feasibility of the media being 
developed. Students are then asked to fill out a respondent questionnaire to provide responses to the Macromedia flash-based learning media.

Based on the results of small group trials and questionnaires that have been given to 15 students of SMA Methodist- 8 Medan class X, it shows that the assessment of the feasibility aspect of the content is $92 \%$ which is categorized as very good / very feasible, and for the user perspective it is $90 \%$ which is categorized as very good / very worthy. The total assessment of basketball teaching media based on Macromedia flash for class X SMA Methodist-8 Medan is $90.76 \%$ categorized as very good / very feasible which means that the product is feasible to be tested to the next stage.

Table 1. Small Group Trial Questionnaire Results

\begin{tabular}{llcccc} 
No. & Rated aspect & $\begin{array}{c}\text { Score that } \\
\text { Obtained } \mathrm{h}\end{array}$ & $\begin{array}{c}\text { Maximum } \\
\text { Score al }\end{array}$ & $\begin{array}{c}\text { Percentase } \\
(\%)\end{array}$ & Category \\
\hline $1 \quad$ Content eligibility & 345 & 375 & $92 \%$ & $\begin{array}{c}\text { Very good/ } \\
\text { Very worthy }\end{array}$ \\
\hline $2 \quad$ User & 540 & 600 & $90 \%$ & $\begin{array}{c}\text { Very good/ } \\
\text { Very worthy }\end{array}$ \\
\hline Total Score & 885 & 975 & $90.76 \%$ & $\begin{array}{c}\text { Very good/ } \\
\text { Very worthy }\end{array}$
\end{tabular}

Based on the results of large group trials and questionnaires that have been given to 30 students of SMA Methodist- 8 Medan class X, it shows that for the assessment of the feasibility aspect of the content $96 \%$ is categorized as very good / very feasible, and for the user perspective it is $95 \%$ which is categorized as good. / worthy. The total assessment of the feasibility test for basketball teaching media based on Macromedia flash for class $\mathrm{X}$ SMA Methodist-8 Medan respondents was $95.38 \%$ categorized as very good / very feasible.

Table 2. Large Group Trial Questionnaire Results

\begin{tabular}{lcccc} 
No. Rated aspect & $\begin{array}{c}\text { Score that } \\
\text { Obtained } \mathrm{h}\end{array}$ & $\begin{array}{c}\text { Maximum } \\
\text { Score al }\end{array}$ & Percentase (\%) & Category \\
\hline $1 \quad$ Content eligibility & 720 & 750 & $96 \%$ & $\begin{array}{c}\text { Very good/ } \\
\text { Very worthy }\end{array}$ \\
\hline $2 \quad$ User & 1140 & 1200 & $95 \%$ & $\begin{array}{c}\text { Very good/ } \\
\text { Very worthy }\end{array}$ \\
\hline Total Score & 1860 & 1950 & $95.38 \%$ & $\begin{array}{c}\text { Very good/ } \\
\text { Very worthy }\end{array}$
\end{tabular}


The fifth stage is evaluation. The evaluation carried out is in the form of development evaluation and evaluation of the feasibility of learning media products. The development evaluation was carried out by media expert lecturers and material experts to determine the feasibility of the developed learning media, and to measure the appropriateness of the development result learning media produced and disseminated and used in SMA Methodist-8 Medan.

Evaluation from media experts is carried out in two stages. The assessment process is carried out by filling out the evaluation sheet that was included during the validation process. Phase I validation from the media aspect is declared fit for production with revisions as recommended, and stage II validation is declared very feasible for production without revision and the product may be tested. The results of stage I evaluation from media experts on the developed product can be seen in the table below.

Table 3. Total Score of Stage I Media Expert Test Assessment

\begin{tabular}{ccccc}
$\begin{array}{c}\text { Number of } \\
\text { media experts }\end{array}$ & $\begin{array}{c}\text { Number of } \\
\text { Assessed aspects }\end{array}$ & $\begin{array}{c}\text { Number of } \\
\text { Items Assessed }\end{array}$ & $\begin{array}{c}\text { Percentage } \\
\text { Rating\% }\end{array}$ & $\begin{array}{c}\text { Percentage } \\
\text { Criteria for } \\
\text { Assessment }\end{array}$ \\
\hline 1 & 2 & 19 & $75.5 \%$ & $\begin{array}{c}\text { GOOD / } \\
\text { DECENT }\end{array}$ \\
\hline
\end{tabular}

From Table 3 it can be seen that the percentage mean value formedia flash macrobased learning media from media experts in stage I, namely $75.7 \%$, then the average value obtained is included in the "Good / Feasible" criteria and can be used. Even though it is included in the Good / proper criteria, there are still some suggestions from media experts. The results of product evaluation in stage II can be seen in table 4 .

Table 4. Total Score of Stage II Media Expert Test Assessment

\begin{tabular}{ccccc}
$\begin{array}{c}\text { Number of } \\
\text { media experts }\end{array}$ & $\begin{array}{c}\text { Number of } \\
\text { Assessed aspects }\end{array}$ & $\begin{array}{c}\text { Number of } \\
\text { Items Assessed }\end{array}$ & $\begin{array}{c}\text { Percentage } \\
\text { Rating\% }\end{array}$ & $\begin{array}{c}\text { Percentage } \\
\text { Criteria for } \\
\text { Assessment }\end{array}$ \\
\hline 1 & 2 & 19 & $86.31 \%$ & $\begin{array}{c}\text { VERY GOOD / } \\
\text { VERY DECENT }\end{array}$ \\
\hline
\end{tabular}

From Table 4.4 it can be seen that the percentage mean value for Macromedia flash based learning media From the media expert in stage II, the mean percentage value was $86.31 \%$, so it is included in the criteria of "very good / very feasible". At this stage there is no longer any advice from experts, and very feasible criteria indicate that the product is feasible.

Evaluation from material experts is carried out in two stages. The assessment process is carried out by filling out the evaluation sheet that was included during the validation process. Phase I validation from the material aspect is declared fit for production with revisions as recommended, and validation at stage II is declared very feasible for production without revision and the product may be tested. The results of stage I evaluation from material experts on the developed product can be seen in the table below. 
Table 5. Total Score of Stage I Material Expert Test

\begin{tabular}{ccccc}
$\begin{array}{c}\text { Number of } \\
\text { media experts }\end{array}$ & $\begin{array}{c}\text { Number of Assessed } \\
\text { aspects }\end{array}$ & $\begin{array}{c}\text { Number of } \\
\text { Items Assessed }\end{array}$ & $\begin{array}{c}\text { Percentage } \\
\text { Rating\% }\end{array}$ & $\begin{array}{c}\text { Percentage } \\
\text { Criteria for } \\
\text { Assessment }\end{array}$ \\
\hline 1 & 2 & 20 & $75 \%$ & $\begin{array}{c}\text { GOOD / } \\
\text { DECENT }\end{array}$ \\
\hline
\end{tabular}

From Table 5 it can be seen that the percentage mean value forlearning materialsfrom material experts in stage I, namely $75 \%$, then the average value obtained is included in the "Good / Feasible" criteria and can be used. Even though it is included in the Good / proper criteria, there are still some suggestions from media experts. The results of product evaluation in stage II can be seen in table 6 .

Table 6. Total Score of Stage II Material Expert Test

\begin{tabular}{ccccc}
$\begin{array}{c}\text { Number of media } \\
\text { experts }\end{array}$ & $\begin{array}{c}\text { Number of } \\
\text { Assessed aspects }\end{array}$ & $\begin{array}{c}\text { Number of } \\
\text { Items Assessed }\end{array}$ & $\begin{array}{c}\text { Percentage } \\
\text { Rating\% }\end{array}$ & $\begin{array}{c}\text { Percentage } \\
\text { Criteria for } \\
\text { Assessment }\end{array}$ \\
\hline 1 & 2 & 20 & $85 \%$ & $\begin{array}{c}\text { VERY GOOD / } \\
\text { VERY DECENT }\end{array}$ \\
\hline
\end{tabular}

\section{Conclusion}

Based on the results of the research, the development of Macromedia Flash based baskes ball teaching materials in health sports physical education lessons is suitable for teaching and learning in schools, especially in high school. Products that have been validated and declared very suitable for use are then tested by their users. From these trials, it was obtained an increase in student interest in learning, meaning that Macromedia flashbased learning has a high influence on student interest in learning. Overall, the assessment of the quality of learning products based on Macromedia flash is included with the criteria "very feasible" to use.

\section{Suggestion}

Based on the conclusions and implications of the suggestions for the research carried out are: (1) Macromedia flash learning media for basic basketball techniques can really be used as an effective independent learning resource, (2) Macromedia flash learning media for the basic technique of this ball can be disseminated through the CD and Falshdisc (3) there is still a need for attention guidance and efforts towards the development of better and more interactive learning resources for learning in teaching and learning in particular, (4) the emergence of new research related to basketball material learning resources and also in the sciences other sciences where the results of research are in the form of products that can later be used by many people. 


\section{References}

Agus Margono. (2010). Permainan Bola Basket. Surakarta: UNS Press.

Ahamadi, Nuril. (2007). Permainan Bola Basket.Surakarta: Era Intermedia.

Ahmad, Sabri. 2007. Strategi Belajar Mengajar dan Micro Teaching, Quantum Teaching. Jakarta : Rineka Cipta

Ali Maksum. (2012). Metodologi Penelitian dalam Olahraga. Surabaya: Unesa University Press.

Amri, Sofan dan Muhammad Rahman. (2013). Strategi dan Disain Pengembangan Sistem Pembelajaran. Jakarta : Prestasi Pustaka Karya.

Amung Ma'mun dan Yudha M. Saputra. (2000). Perkembangan Gerak dan Belajar Gerak. Jakarta: Departemen Pendidikan dan Kebudayaan.

Arsani. Et al. (2020). Differences in Motivational Orientation in Physical Education in terms of Gender Differences. Budapest International Research and Critics in Linguistics and Education (BirLE) Journal. P. 1428-1434.

Arsyad, Azhar. (2007). Media Pengajaran. Jakarta: PT Raja Grafindo Persada

Asyhar, Rayandra. (2011). Kreatif Mengembangkan Media Pembelajaran. Jakarta: GP pres

Bailey. (1982). Metode Penelitian. Diakses pada 20 Juli 2018. https://www.slideshare.net/wlucy1/metode-penelitian-27122596

Dedy Sumiyarsono. (2002). Keterampilan Bolabasket. Yogyakarta: FIK UNY.

Djamarah, Syaiful Bahri dan Aswan Zain. (2010). Strategi Belajar Mengajar. Jakarta: Rineka Cipta

Dwipayanti,A,sudhayati,R., dan Parmiti,.P. (2013). Pengaruh Model Pembelajaran ADDIE Berbantuan Media Konkret Terhadap Hasil Belajar ipa Siswa Kelas V SD 1 Pangkung paruk. Skripsi: Universitas Pendidikan Ganesha.

Edwards, M. (2014). Candida albicans - The Foundation Of Illness. https://www.shiftfrequency.com/michael-edwards-candida-albicans-thefoundationof-illness/. Diakses pada tanggal 27 April 2019.

Endang, Mulyatiningsih. (2013). Metode Penelitian Terapan Bidang Pendidikan. Bandung: Alfabeta.

Fauzi, Burhan dan Kusrini. (2014). "Pengembangan Media Pembelajaran Multimedia Interaktif Pada Materi Pokok Teorema Pythagoras". Jurnal Ilmiah Pendidikan Matematika: Universitas Negeri Surabaya.

FIBA. (2010). Rules. United States.

Fiba. (2012). Bola Basket Untuk Semua. Jakarta: Persatuan Bola Basket Seluruh Indonesia. (Alih Bahasa: Bidang III PB PERBASI).

Hany Ahmed Ahmed Abd El-Aal. (2012). Effect of Educational Module on Basic Basketball Skills Performance in Junior of Basketball. World Journal of Sport Sciences 6 (4): 428-431.

Hariyanto. (2015). Implementasi Belajar \& Pembelajaran. Bandung: Remaja Rosdakarya

Hernowo. (2005). Menjadi Guru yang Mau dan Mampu Mengajar secara Menyenangkan. Bandung: MLC.

Irsyada. (2000). Bola Basket. Jakarta: Depdiknas. Dirjen Dikdasmen bekerjasama dengan Dirjen olahraga.

Kemendikbud. (2014). Konsep dan Implementasi Kurikulum 2013. Jakarta: Kementrian Pendidikan dan Kebudayaan.

Khairunnisa. (2016). "Aplikasi Media Pembelajaran Olahraga Bola Basket Menggunakan Adobe Flash". Jurnal Sistem Informasi: Universitas Harapan Medan. ISSN 25795341 
Koesnandar,Ade. (2003). Evaluasi Multimedia Pembelajaran. Jakarta: Pustekkom Diknas

Muhammad Muhyi Faruq.(2009). Meningkatkan Kebugaran Jasmani Melalui Permainan Bolabasket. Surabaya: PT Gramedia Widiasarana Indonesia

Musdiani et al. (2019). Analysis the Role of Headmaster in Applying Quality of Education in Primary School Districts, Aceh Barat. Budapest International Research and Critics in Linguistics and Education (BirLE) Journal. P. 27-35.

PERBASI. (2012). Peraturan Resmi Bola Basket. Jakarta.

Schmidt.R.A. (1991). Motor Learning and Performance, From Principles to practice.Champaign: Human Kinetcs Books.

Sianturi , Fricles Ariwisanto. (2016). “Aplikasi Pembelajaran Penjaskes Olahraga Basket Menggunakan Metode Computer Assisted Instruction (Cai)". Journal Of Informatic: Pelita Nusantara. e-ISSN 2541-3724

Sugiyono. (2013). Metode Penelitian Pendidikan Pendekatan Kuantitatif, Kualitatif, dan R\&D. Bandung: Alfabeta.

Sugiyono. (2014). Metode Penelitian Pendidikan Pendekatan Kuantitatif, Kualitatif, dan R\&D. Bandung: Alfabeta.

Sugiyono. (2015). Metode Penelitian Kombinasi (Mix Methods). Bandung: Alfabeta.

Sukamti, Endang Rini. (2001). Perkembangan Motorik Kasar Anak Usia Dini Sebagai Dasar Menuju Prestasi Olah Raga MS. Yogyakarta: FIK-UNY

Sutopo, Ariesto Hadi. (2003). Multimedia Interaktif dan Flash. Yogyakarta: PT Graha Ilmu Oliver,Jon. (2004). Dasar- Dasar Bola Basket. Klaten: Pakarnya Pustaka

Tim Pengembangan Wahana Komputer. (2006). Jakarta: Salemba Empat , Peraturan Pemerintah Republik Indonesia Nomor 19 tahun 2005 tentang Standar Nasional pendidikan, Jakarta: Departemen Pendidikan Nasional, 2005 